\title{
Sulfide detoxification and tolerance in Halicryptus spinulosus (Priapulida): a multiple strategy
}

\author{
Rolf Oeschger ${ }^{1}$, Russell D. Vetter ${ }^{2, *}$ \\ ${ }^{1}$ Universität Bremen, Meereszoologie, Außenstelle Bremerhaven, Bürgermeister-Smidt-Str. 20, W-2850 Bremerhaven, \\ Germany \\ ${ }^{2}$ Scripps Institution of Oceanography, Marine Biology Research Division A-002, La Jolla, California 92093, USA
}

\begin{abstract}
The detoxification potential of Halicryptus spinulosus in the presence of sulfide was studied. The worms are able to cope with considerable amounts of sulfide. They benefit from several survival strategies for controlling sulfide dose and detoxifying sulfide that enters the body. When oxygen and sulfide occur concurrently in the environment sulfide can either initially be excluded or internal concentration kept low by the animals. Non-toxic thiosulfate, the main detoxification product, accumulates up to $3856 \pm 997 \mu \mathrm{M}$ in the hemolymph. Sulfide has an overriding influence on the aerobic metabolism and imposes anaerobiosis even though oxygen is available, i.e. sulfide-induced anaerobiosis. Succinate, an indicator of anaerobic metabolism, accumulates during persistent oxic sulfide incubation to $12.3 \pm 2.3 \mu \mathrm{mol} \mathrm{ml} \mathrm{m}^{-1}$ in hemolymph and to $3.0 \pm 1.3 \mu \mathrm{mol} \mathrm{g}{ }^{-1}$ fresh mass in body wall after $10 \mathrm{~d}$. During anoxic sulfide exposure, the animals make use of graded strategies. Some sulfide is immobilised in an external barrier due to iron-sulfide formation. The iron-sulfide compound results in a conspicuous blackening of the animal and its blood. This blackening is fully reversible upon receiving oxygen again. Detoxification to thiosulfate, depending on the oxygen storage capacity of the hemolymph, amounted to only a minor level, with a maximum of $172 \pm 49 \mu \mathrm{M}$ in the hemolymph after $1 \mathrm{~d}$ of incubation. Sulfide also binds to a presently unknown hemolymphic factor. This binding may temporarily protect mitochondria, a main location of sulfide detoxification. The mitochondrial enzyme for aerobic metabolism, cytochrome $\mathrm{c}$ oxidase, is inhibited by low sulfide levels in vitro $\left(K_{1} 1.05 \pm 0.22\right.$ $\mu \mathrm{M})$, and has a much higher in vivo resistance in whole animals. Catalase, another sulfide sensitive enzyme, has a $K_{\mathrm{i}}$ of ca $200 \mu \mathrm{M}$ in vitro and is unaffected in vivo. Internal sulfide concentration in the hemolymph increases ca 3 -fold $(570 \pm 298 \mu \mathrm{M})$ over external levels during long-term exposure experiments with $200 \mu \mathrm{M}$ sulfide. The survival in spite of such an elevated amount of internal sulfide accumulation is unprecedented for a marine invertebrate without endosymbionts. The worms can passively outlast raised environmental sulfide concentrations by their high capacity for anaerobic metabolism.
\end{abstract}

\section{INTRODUCTION}

Recent studies stress the importance of sulfide in a variety of marine environments other than deep-sea hydrothermal vents (Bagarinao \& Vetter 1989, 1990, Cary et al. 1989b, Schiemer et al. 1990, Llansó 1991, Ott et al. 1991, Vismann 1991a, Völkel \& Grieshaber 1992).

Although sulfide has been known to be abundant in marine sediments, this highly toxic compound has usually been disregarded as a factor influencing the distribution of soft bottom benthic macrofauna. Exposure and impact of sulfide on marine invertebrates have

\footnotetext{
- Present address: NOAA, Southwest Fishery Sciences Center, La Jolla, California 92038, USA
}

attained considerable attention during the last years due to the discovery of the spectacular deep-sea hydrothermal vents (for reviews e.g. Somero et al. 1989, Fisher 1990), which has stimulated intensive research on this topic. The well-aerated sulfide-containing deep-sea vents are mostly inhabited by flourishing populations of marine macrofauna with sulfide-oxidising endosymbiotic bacteria (e.g. Cavanaugh et al. 1981, Powell \& Somero 1983, Jones 1985, Fisher 1990).

Sulfide-rich marine soft sediments have different features. Constant anoxic sulfidic sediments like those of the deep basins of the Black Sea and the Baltic Sea are without higher organisms and only the borders of these areas are colonised by some invertebrates. A different situation is encountered in areas with sea- 
sonal fluctuations of oxygen availability and subsequent sulfide development. Sulfide is produced in the anoxic sediment layers. When oxygen becomes limited the anoxic layer with the sulfide expands upwards. Such biotopes are either populated by opportunistic species with little or no capacity for anaerobic metabolism or by species with an extraordinary anaerobic capacity and sulfide resistance. Opportunistic species are able to survive only during intermittent periods when oxygen is available and sulfide is absent. With deteriorating conditions these populations will be extinguished. In areas like those of the Western Baltic only a few species are able to resist frequent adverse environmental conditions. Earlier studies on such species showed a high anaerobic capacity (Theede et al. 1969, Theede 1984, Oeschger 1990). The importance of anaerobiosis as a strategy to avoid sulfide toxicity has yet to be intensively addressed.

Halicryptus spinulosus, a priapulid worm and one of those few species able to persist in anoxic soft sediments of the Western Baltic, is frequently exposed to elevated sulfide levels. It is an important faunal component with high abundances and it survives for extended periods at environmental anoxia (Weigelt \& Rumohr 1986). Previous studies on $H$. spinulosus dealt with its anaerobic capacity (Oeschger 1990, Oeschger \& Storey 1990), energetic studies (Oeschger et al. 1992), and with histological and ultrastructural peculiarities of sulfide impact on the animals (Oeschger \& Janssen 1991, Janssen \& Oeschger 1992).

The objective of this paper was to study sulfide detoxification and tolerance in Halicryptus spinulosus. We conducted studies on whole animals to look at the oxic and anoxic sulfide detoxification potential and to assess the involvement of an anaerobic metabolism. Further points of interest were the effects of sulfide exposure on enzymes. Shipboard studies on the actual sulfide contents in worms and the sediment were performed to complete this study.

\section{MATERIAL AND METHODS}

Sampling. Halicryptus spinulosus were dredged during several cruises between summer 1990 and winter 1991/92 from muddy soft sediments at a water depth of $20 \mathrm{~m}$ in Kiel Bight, Western Baltic Sea. Specimens were transported live in a cooler to the Scripps Oceanographic Institution, La Jolla, California, USA, in summer 1990. They were kept unfed in aerated seawater at $9.5 \pm 0.5^{\circ} \mathrm{C}$ and $22 \% \mathrm{~S}$ in original sediment. Prior to experiments worms were kept at least $5 \mathrm{~d}$ in aerated seawater without sediment.

During 1990 to 1992 some worms were analysed for sulfide contents directly after capture aboard the research vessel. In November 1991 a specially designed light-weight gravity sediment corer (Meischner \& Rumohr 1974) was used from shipboard to obtain pore water from undisturbed sediment cores (diameter $80 \mathrm{~mm}$ ) of the sampling area. Sediment was centrifuged immediately aboard ship and analysed for sulfide contents after Cline (1969), using the 1 to $40 \mu \mathrm{M}$ range of reagents.

Oxic sulfide incubation. A continuous flow-through system with a chamber volume of about $1.5 \mathrm{l}$ was used. A peristaltic pump delivered supersaturated $(107 \%)$ seawater $\left(10 \pm 0.5^{\circ} \mathrm{C}, 22 \% \mathrm{~S}\right)$ at a constant flow rate of about $800 \mathrm{ml} \mathrm{h}^{-1}$. A sulfide stock solution $(3.2 \mathrm{mM}$, pH adjusted with $\mathrm{HCl}$ to 7.0 ) was delivered by another peristaltic pump and mixed with seawater before entering the incubation chamber to obtain the experimental concentration. During the experiments oxygen and sulfide concentrations were regularly monitored. For oxygen measurements a modified Winkler procedure (after Ingvorsen \& Jörgensen 1979) had to be used due to sulfide interaction with the conventional determination: sulfide was precipitated with $2 \mathrm{~N} \mathrm{ZnSO}_{4}$ in the presence of $1 \mathrm{~N} \mathrm{NaOH}$ and oxygen could then be reliably estimated in the overlaying seawater. Oxygen concentrations were mainly in the range of 90 to $97 \%$, referred to as 'oxic incubation'. Sulfide concentrations were in the range of $200 \pm 40 \mu \mathrm{M}$ and $\mathrm{pH}$ in the chamber was between 7.84 and 7.98. In this paper the term sulfide refers to total sulfide $\left(\mathrm{H}_{2} \mathrm{~S}, \mathrm{HS}^{-}\right.$and $\left.\mathrm{S}^{2-}\right)$ unless otherwise stated

Anoxic sulfide incubation. For anoxic sulfide exposure experiments $(200 \mu \mathrm{M})$, worms were incubated in an airtight experimental chamber containing $500 \mathrm{ml}$ seawater $\left(9.5 \pm 0.5^{\circ} \mathrm{C}, 22 \% \mathrm{~S}\right)$. Sulfide levels were obtained by adding $\mathrm{Na}_{2} \mathrm{~S} \cdot 9 \mathrm{H}_{2} \mathrm{O}$ crystals to nitrogen or argon-bubbled oxygen-free seawater to a given final concentration of ca $200 \mu \mathrm{M}$ and $\mathrm{pH}$ was adjusted to 8.0 with $\mathrm{HCl}$. After sealing the chamber, an argon atmosphere was introduced to cover the surface additionally against oxygen. During exposure experiments triplicate water samples were taken and the sulfide concentration was measured by the methylene blue method (Cline 1969). Due to oxidation during incubation, $\mathrm{H}_{2} \mathrm{~S}$ concentrations were readjusted daily to the intended level. This happened particularly during the first 3 to $4 \mathrm{~d}$ of incubation, while sulfide concentration was nearly unchanged afterwards. To avoid the accumulation of toxic metabolites, the seawater was changed every 3 to $4 \mathrm{~d}$. For anoxic sulfide exposure we chose a concentration of $200 \mu \mathrm{M}$ since this is a realistic concentration that the worms encounter during long-term environmental oxygen deficiency.

Enzyme assays. Cytochrome c oxidase: Activity of cytochrome c oxidase (E.C. 1.9.3.1) in freshly sampled body wall tissue and hemolymph of Halicryptus 
spinulosus was measured after Hand \& Somero (1983). In vitro sulfide inhibition experiments were performed on homogenates from unexposed worms using different sulfide concentrations to calculate the $50 \%$ inhibition constants ( $K_{\mathrm{j}}$ or $I_{50}$-value). Activity of cytochrome c oxidase was also assayed in specimens exposed to $200 \mu \mathrm{M}$ sulfide for $8 \mathrm{~d}\left(22 \% \mathrm{~S}, 9.5 \pm 0.5^{\circ} \mathrm{C}\right)$.

Catalase: Activity of catalase (E.C. 1.11.1.6) was determined according to Aebi (1985). Samples were homogenised in $40 \mathrm{mM}$ potassium phosphate buffer. The homogenate was assayed in potassium phosphate buffer $\left(50 \mathrm{mM}, \mathrm{pH} 7.0\right.$ ) containing $\mathrm{H}_{2} \mathrm{O}_{2}$ as substrate (35 $\mathrm{\mu l}$ of a $30 \% \mathrm{H}_{2} \mathrm{O}_{2}$ stock solution diluted with $10 \mathrm{ml}$ of phosphate buffer). From this solution, $350 \mu \mathrm{l}$ were added with a varying volume of phosphate buffer and homogenate to a final volume of $1 \mathrm{ml}$. The initial absorbance at $240 \mathrm{~nm}$ was in the range of 0.500 , and time needed for a decrease from 0.450 to 0.400 was recorded to calculate the activity of catalase. Since this reaction exhibits abnormal kinetics, the rate constant of the first order reaction $[k$, according to the equation $k=$ $\left.1 / t \cdot \ln \left(E_{0} / E\right)\right]$ has to be converted to units. One unit is defined as the decomposition of $1 \mu \mathrm{mol} \mathrm{H}_{2} \mathrm{O}_{2} \mathrm{~min}^{-1}$, while the concentration of $\mathrm{H}_{2} \mathrm{O}_{2}$ decreases from 10.3 umol ml ${ }^{-1}\left(\mathrm{abs}_{240}=0.450\right)$ to $9.2 \mu \mathrm{mol} \mathrm{ml} l^{-1}\left(\mathrm{abs}_{240}=\right.$ $0.400)$.

Bovine liver catalase (Sigma) was used as a reference standard. Sodium azide $(1 \mathrm{mM})$ was used as an inhibitor of catalase. In vitro inhibition of different concentrations of sulfide were assayed and $I_{50}$-values were calculated.

Succinate. The anaerobic metabolite succinate was measured using the standard enzymatic determination after Beutler (1985).

Chromatography of sulfur compounds in body wall tissue and hemolymph. Determination and quantification of sulfur compounds was done by reversed-phase high-performance liquid chromatography (HPLC) (Fahey \& Newton 1987, Vetter et al. 1989), with monobromobimane $(\mathrm{mBBr})$, a synthetic molecule that covalently binds reduced sulfur compounds (thiols) and makes them fluorescent. The term 'thiol' refers to sulfhydryl compounds which react with $\mathrm{mBBr}$. In this paper the term is extended to sulfite, sulfide and thiosulfate. Samples were run on a computer-controlled Kontron HPLC system, excitation wavelength of the detector was set at $350 \mathrm{~nm}$, emission wavelength on $480 \mathrm{~nm}$. Quantification was achieved by comparing the peaks with authentic standards: fluorescence of the sulfur compounds in the samples was measured against standard mixtures of sulfide, thiosulfate, sulfite, cysteine, and glutathione. To ascertain that the peaks detected were sulfur compounds, a subsample was derivatized with non-fluorescent 2-dipyridyl-sulfide (PDS), which also binds sulfur species but prevents
$\mathrm{mBBr}$ binding. After the experiments, body wall tissue was immediately homogenised in an ice-cold HEPESbuffer ( $\mathrm{N}$-2-hydroxyethylpiperazine-N'-2-ethane sulfonic acid, $200 \mathrm{mM}, \mathrm{pH} 8.0$ ) containing the $\mathrm{mBBr}$ and prepared for further HPLC analysis (Vetter et al. 1989). Hemolymph was prepared without pretreatment. Samples were either directly analysed or stored at $4^{\circ} \mathrm{C}$. Storage at $4^{\circ} \mathrm{C}$ had no significant effect on content of sulfur compounds (Fahey \& Newton 1987).

In some experiments oxidation of sulfide and conversion to other metabolites was studied using radiolabelled $\mathrm{Na}_{2}{ }^{35} \mathrm{~S}$ (Amersham). The HPLC system was able to detect fluorescence and radioactivity of ${ }^{35} \mathrm{~S}$ simultaneously, the latter by a flow-through in-line scintillation counter (Vetter et al. 1989).

Hemolymph binding. To detect the possible presence of a sulfide binding component in the hemolymph of Halicryptus spinulosus, we used ${ }^{35} \mathrm{~S}$ radiolabelled sulfide in connection with a dialysis chamber. Hemolymph samples from 4 to 8 unexposed oxic controls, or anoxic worms which had been exposed for $10 \mathrm{~d}$ to a sulfide concentration of $200 \mu \mathrm{M}$, were placed in plugged cylinders of dialysis tubing (molecular weight cut off: ca $12 \mathrm{kDa}$ ) using a Hamilton syringe (final sample volume: $1 \mathrm{ml}$ ). The dialysis bag was placed in a water-jacketed stirring reservoir of $12 \mathrm{ml}$ buffer volume (seawater of $22 \% \mathrm{~S}$, buffered with 10 mM Tris, pH 7.5). Control samples without hemolymph consisted of buffered seawater and were also placed in separate dialysis bags. Cold and radiolabelled sulfide was added to the outer buffer to a final concentration of $200 \mu \mathrm{M}$ in a ratio $3: 1$. The buffer was moderately degassed prior to use to prevent an immediate spontaneous oxidation of the sulfide. Repeated sampling and scintillation counting of the ${ }^{35} \mathrm{~S}$ radioactivity in the samples and the control bag showed the diffusion and final equilibrium. The measure for binding capacity was the difference in counts between buffer control and hemolymph samples.

Isolation and respiration of mitochondria. For one mitochondrial isolation, ca 15 to 20 worms ( 8 to $9 \mathrm{~g}$ fresh mass) were homogenised. The body wall of freshly dissected worms was cleansed of adhering coelomic fluid and other tissues, rinsed in isolation buffer, and cut in coarse pieces. This suspension was homogenised using a 10 to $15 \mathrm{~s}$ burst (9500 rpm) of an Ultra Turrax tissue homogenizer, and further homogenised in a Potter-Elvehjem homogenizer with 3 to 5 passes of a teflon pestle (final volume: ca 8 to $9 \mathrm{~g}$ fresh mass per $30 \mathrm{ml}$ isolation buffer). The isolation buffers consisted of 350 to $500 \mathrm{mM}$ glycine, 170 to 200 $\mathrm{mM}$ sucrose, 2 mM EGTA lethylene glycol-bis-( $\beta$ aminoethyl ether) $\mathrm{N}, \mathrm{N}_{1} \mathrm{~N}^{\prime}, \mathrm{N}^{\prime}$-tetraacetic acid], $2 \mathrm{mM}$ EDTA (ethylene diamine- $N, N_{,} N^{\prime}, N^{\prime}$-tetraacetic acid), 25 to $100 \mathrm{mM} \mathrm{KCl}, 20 \mathrm{mM}$ HEPES, $0.2 \%$ BSA (bovine 
serum albumin, essentially fatty acid free), $\mathrm{pH} 7.4$. The resulting preparation was centrifuged at $600 \mathrm{~g}$ for $6 \mathrm{~min}$ to remove cellular debris. A second spin at $13500 \mathrm{~g}$ for 15 min was used to pellet the mitochondria of the supernatant of the first spin. The upper layer of the resulting pellet was resuspended in 0.5 to $1 \mathrm{ml}$ of isolation buffer. Any further purification steps lead to significantly reduced or no mitochondrial activity and were omitted. Activity of GDH (glutamate dehydrogenase) was used as a mitochondrial marker enzyme. Mitochondrial preparations usually contained 2 to $4 \mathrm{mg}$ protein $\mathrm{ml}^{-1}$ (determined by the Biuret method).

Assays of mitochondrial respiration were monitored at $13^{\circ} \mathrm{C}$ in an oxygen respiration chamber described by O'Brien \& Vetter (1990) to determine the respiratory control ratio (RCR) (Estabrook 1967). The respiration medium was the same as used for isolation plus up to $10 \mathrm{mM}$ potassium phosphate and $7 \mathrm{mM} 2$-oxoglutarate. For oxygen respiration measurements of the mitochondria, a gold-coated sulfide-insensitive Clark type oxygen electrode (Eschweiler, Kiel, Germany) was used.

\section{RESULTS}

\section{Environmental sulfide}

\section{Sediment}

In Fig. 1 the sulfide concentration in the pore water of the sampling location in November 1991 is shown (Western Baltic Sea: $54^{\circ} 38.1^{\prime} \mathrm{N}, 10^{\circ} 20.5^{\prime} \mathrm{E}$; water depth $21 \mathrm{~m}$ ). Halicryptus spinulosus is found down to $30 \mathrm{~cm}$ sediment depth. Results indicate that the worms can be exposed to a concentration of up to $665 \mu \mathrm{M}$ sulfide in the pore water. On earlier cruises the directly measured sulfide concentrations in samples of pooled pore water from 0 to $5 \mathrm{~cm}$ sediment depth were: 30 to $49 \mu \mathrm{M}$ (27 November 1990); 4 to $29 \mu \mathrm{M}$ (27 February 1991 ), and 2 to $16 \mu \mathrm{M}$ (2 July 1991).

\section{Worms}

In Table 1 sulfide and thiosulfate concentrations in worms from different cruises are compiled. Hemolymph samples were taken on shipboard immediately after obtaining the worms to determine actual in situ values. Some Halicryptus spinulosus were subsequently kept in the laboratory in aerated seawater without sediment to monitor the course of the sulfide and thiosulfate concentration. On some occasions nearly all dredged $H$. spinulosus were black, reflecting sulfide exposure. During collection, both pale to brownish-looking and black worms were caught, indi- cating a patchy distribution of sulfide in their habitat. Internal sulfide concentrations decreased during the laboratory incubation and thiosulfate was not detectable, with one exception showing small amounts.

\section{Sulfide incubation experiments}

\section{Whole animals}

Halicryptus spinulosus usually has a pale to dark brown colour when living in oxidised sediment without sulfide. During the experiments some individuals started to turn black on the surface of their body wall after only about $1 \mathrm{~h}$ exposure to $200 \mu \mathrm{M}$ sulfide containing anoxic seawater. The blackening intensified after $2 \mathrm{~h}$ and the body wall of all worms was completely black after 5 to $6 \mathrm{~h}$ of incubation, whereas the hemerythrin-containing hemolymph turned completely black after ca $3 \mathrm{~d}$ of incubation.

On one occasion we observed that the process of regaining the usual pale brown colour after being transferred to aerated seawater started from the middle of the body wall, and the worms regained their normal colour within 1 to $2 \mathrm{~min}$. Such a rapid colour change might indicate the involvement of an enzyme-mediated mechanism in reversing the iron-sulfide interaction. During oxic sulfide incubation $(200 \mu \mathrm{M})$ about $50 \%$ of the worms turned black after ca $3 \mathrm{~d}$, but not as intensely as during anoxic sulfide incubation.

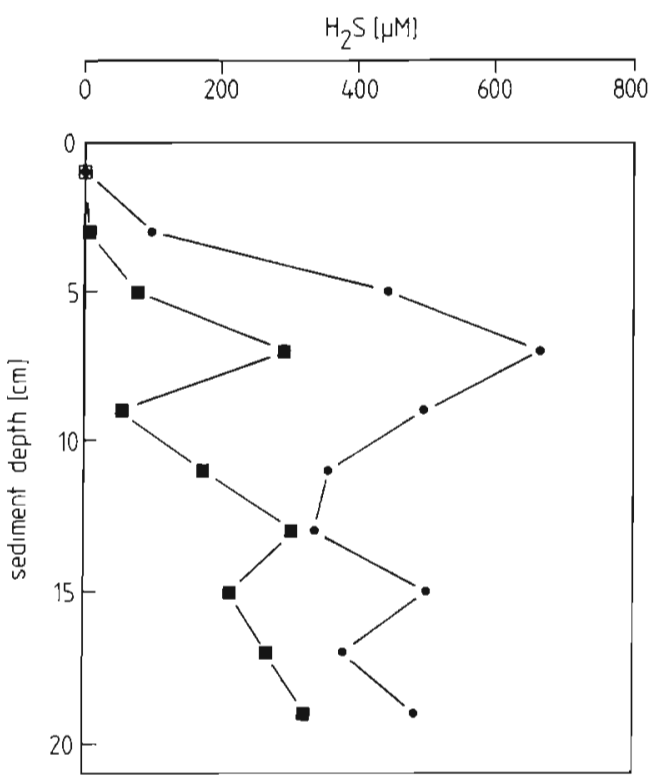

Fig. 1. Sulfide concentration in pore water (in $\mu \mathrm{M}$ ) from the sampling location of Halicryptus spinulosus in the Western Baltic Sea in November 1991 determined by the methylene

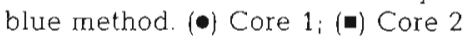


Sulfide concentration in whole animals was $6.6 \pm$ $4.3 \mathrm{nmol} \mathrm{g}^{-1}$ fresh mass ( $\mathrm{n}=5$ ), while thiosulfate levels were $1.02 \pm 1.39 \mathrm{nmol} \mathrm{g}^{-1}$ fresh mass $(\mathrm{n}=5)$.

\section{Body wall}

During oxic sulfide incubation $(200 \mu \mathrm{M})$, sulfide started to accumulate in body wall tissue of Halicryptus spinulosus from an initial $0.028 \pm 0.014 \mu \mathrm{mol} \mathrm{g} \mathrm{g}^{-1}$ fresh mass $(n=4)$ in control worms to $0.106 \pm 0.164 \mu \mathrm{mol} \mathrm{g}^{-1}$ fresh mass $(n=4)$ after $1 \mathrm{~d}$ of exposure. After $10 \mathrm{~d}$, sulfide concentration rose to $0.201 \pm 0.072 \mu \mathrm{mol} \mathrm{g} \mathrm{g}^{-1}$ fresh mass $(n=6)$ (Fig. 2a). Thiosulfate, an oxidation product of sulfide, increases strongly after $1 \mathrm{~d}$ of incubation from an initial $0.07 \pm 0.03 \mu \mathrm{mol} \mathrm{g} \mathrm{g}^{-1}$ fresh mass $(\mathrm{n}=4)$ to $0.275 \pm 0.143 \mu \mathrm{mol} \mathrm{g}{ }^{-1}$ fresh mass $(n=5)$. reaching a maximum of $0.779 \pm 0.14 \mu \mathrm{mol} \mathrm{g}^{-1}$ fresh mass ( $\mathrm{n}=5$ ) after $4 \mathrm{~d}$. Thiosulfate concentration tended to decrease to $0.422 \pm 0.17 \mathrm{umol} \mathrm{g}^{-1}$ fresh mass $(\mathrm{n}=5)$ at the end of the experiments (Fig. 2b).

In anoxic sulfide incubations $(200 \mu \mathrm{M})$, a large accumulation of sulfide was measured in worms. Values increased from $0.079 \pm 0.037 \mu \mathrm{mol} \mathrm{g} \mathrm{g}^{-1}$ fresh mass $(\mathrm{n}=6)$ in controls to $0.644 \pm 0.286 \mu \mathrm{mol} \mathrm{g}^{-1}$ fresh mass $(\mathrm{n}=14$ ) after $10 \mathrm{~d}$. We assessed a possible effect of the mucus covering the outer body wall on sulfide values in body wall tissue. Some samples of a $10 \mathrm{~d}$ anoxic incubation $(200 \mu \mathrm{M})$ were sonicated for $30 \mathrm{~s}$ to strip off the mucus prior to analysis. Values of $0.487 \pm 0.398 \mu \mathrm{mol}$ $\mathrm{g}^{-1}$ fresh mass $(\mathrm{n}=8$ ) for sonicated tissues tended to be smaller compared to untreated individuals. After sonication worms were almost pale; their creamy looking gonads and the black hemolymph became visible.

Only minor amounts of thiosulfate were produced after $1 \mathrm{~d}$ of incubation $\left(0.036 \pm 0.027 \mu \mathrm{mol} \mathrm{g}^{-1}\right.$ fresh mass, $n=5$ ) and tended to accumulate at the end of the $10 \mathrm{~d}$ experiments $\left(0.092 \pm 0.045 \mu \mathrm{mol} \mathrm{g}{ }^{-1}\right.$ fresh mass, $\mathrm{n}=14$ ). During anoxic sulfide incubations, thiosulfate concentrations amounted to only a minor fraction of that found during oxic sulfide incubation. Sulfite $\left(\mathrm{SO}_{3}{ }^{2-}\right), \mathrm{GSH}$ (reduced glutathione) and cysteine were also measured. Sulfite and cysteine were detectable only in traces in control individuals as well as in incubated specimens (data not shown). The concentration of GSH did not differ significantly during the course of the experiments. Concentrations ranged from $0.462 \pm$ $0.17 \mu \mathrm{mol} \mathrm{g}{ }^{-1}$ fresh mass $(n=7)$ in controls to $0.40 \pm$ $0.118 \mu \mathrm{mol} \mathrm{g}^{-1}$ fresh mass $(n=6)$ in oxic incubated specimens after $10 \mathrm{~d}$, and to $0.448 \pm 0.114 \mu \mathrm{mol} \mathrm{g} \mathrm{g}^{-1}$ fresh mass $(n=14)$ after $10 \mathrm{~d}$ of anoxia.

\section{Hemolymph}

In a short-term experiment $100 \mu$ of hemolymph was incubated with ${ }^{35} \mathrm{~S}$-sulfide for $6 \mathrm{~h}$. Analysis showed some ${ }^{35} \mathrm{~S}$-sulfate formation due to chemical oxidation, suggesting that sulfate did not participate in sulfide detoxification. Double radiolabelled thiosulfate $\left({ }^{35} \mathrm{~S}\right.$ ${ }^{35} \mathrm{SO}_{3}{ }^{2-}$ ) was identified as the detoxification product.

At the beginning of oxic sulfide incubation $(200 \mu \mathrm{M})$,
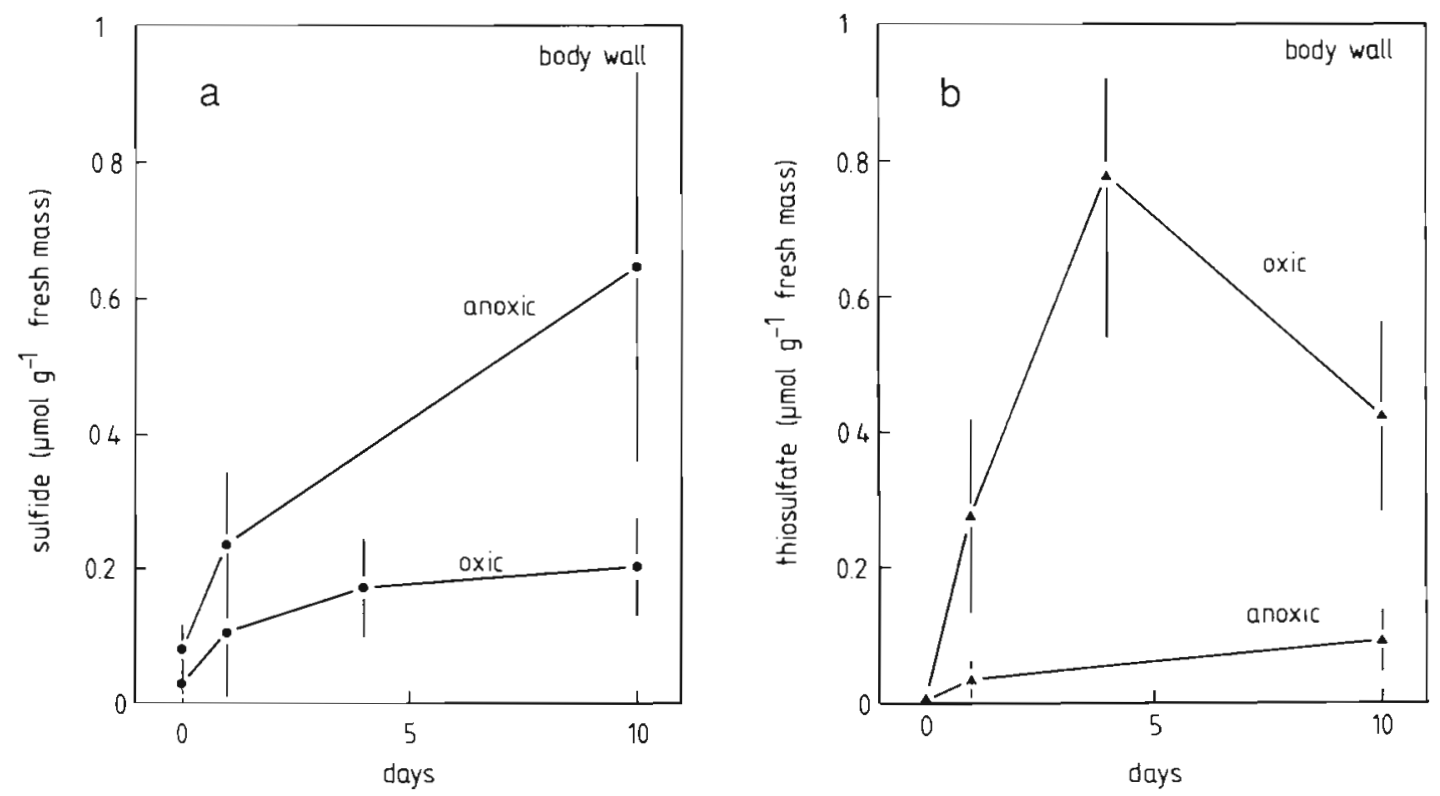

Fig. 2. Halicryptus spinulosus. Concentrations ( \pm SD) of (a) sulfide and (b) thiosulfate in body wall tissue during oxic and anoxic sulfide incubation after 1,4 and $10 \mathrm{~d}$ at an external sulfide concentration of $200 \mu \mathrm{M}$ in seawater $\left(9.5 \pm 0.5^{\circ} \mathrm{C}, 22 \%\right.$ S). Values are in $\mu \mathrm{mol} \mathrm{g}^{-1}$ fresh mass. Data are means of 5 to 14 individuals 

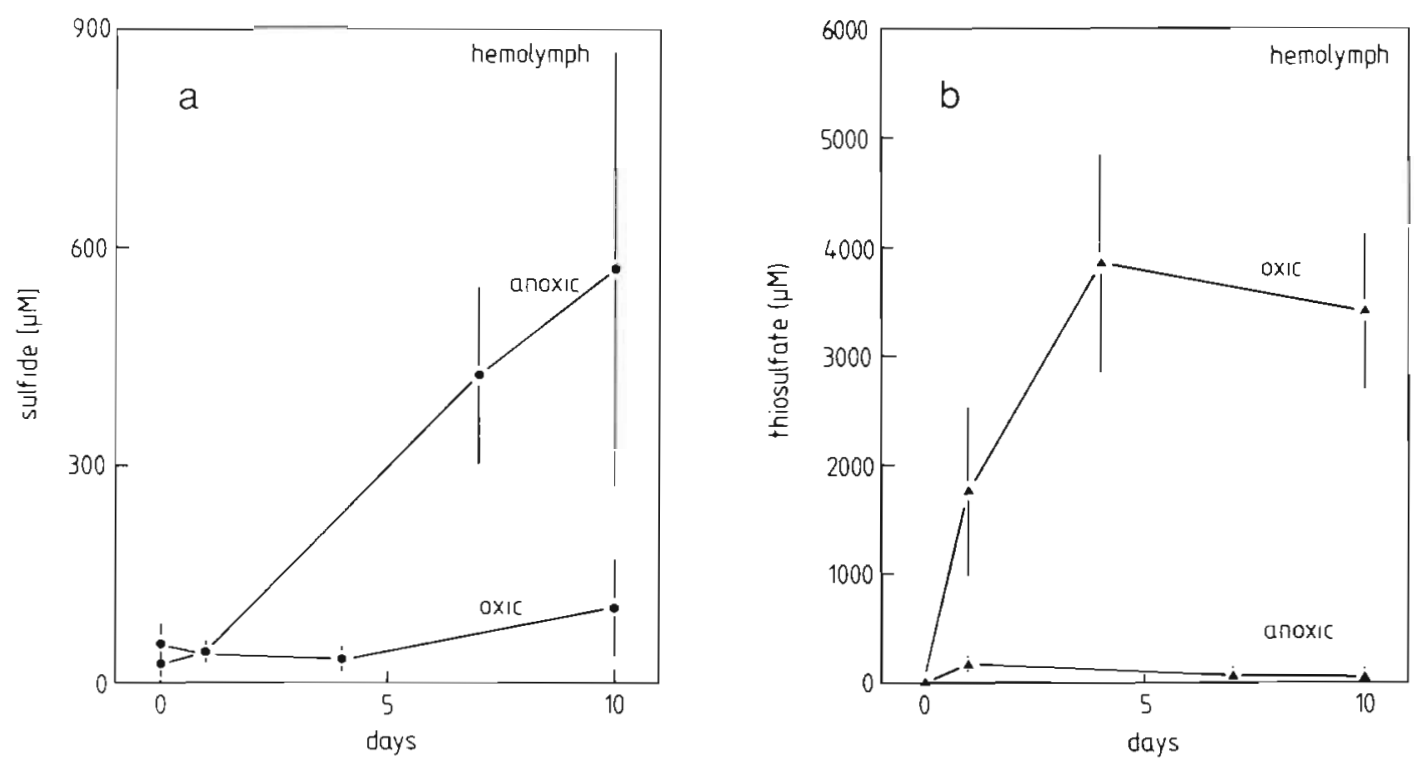

Fig. 3. Halicryptus spinulosus. Concentrations ( \pm SD) of (a) sulfide and (b) thiosulfate in hemolymph during oxic and anoxic sulfide incubation after $1,4,7$, and $10 \mathrm{~d}$ of an external sulfide concentration of $200 \mu \mathrm{M}$ in seawater $\left(9.5 \pm 0.5^{\circ} \mathrm{C}, 22 \% \mathrm{~S}\right) . \mathrm{Values}$ are in $\mu \mathrm{M}$. Data are means of 5 to 18 individuals

Halicryptus spinulosus was able to keep the sulfide from entering the hemolymph. In the course of the experiments, sulfide concentration varied between 53 $\pm 29 \mu \mathrm{M}(\mathrm{n}=5)$ in controls to $34 \pm 17 \mu \mathrm{M}(\mathrm{n}=5)$ after $4 \mathrm{~d}$ of incubation, but was $104 \pm 67 \mu \mathrm{M}$ after $10 \mathrm{~d}$ $(\mathrm{n}=6)$ (Fig. 3a). Thiosulfate increased from $6 \pm 13 \mu \mathrm{M}$ $(n=5)$ in controls to $1756 \pm 781 \mu \mathrm{M}(\mathrm{n}=5)$ after $1 \mathrm{~d}$ of incubation, reaching a maximum of $3856 \pm 997 \mu \mathrm{M}$ ( $\mathrm{n}=5$ ) at $4 \mathrm{~d}$, while it tended to decrease slightly to $3410 \pm 718 \mu \mathrm{M}(\mathrm{n}=6)$ after $10 \mathrm{~d}$ (Fig. $3 \mathrm{~b}$ ).

The hemolymph exhibited a different characteristic during anoxic sulfide exposure $(200 \mu \mathrm{M})$. After $1 \mathrm{~d}$ of incubation sulfide concentration $(43 \pm 15 \mu \mathrm{M}, \mathrm{n}=5)$ did not differ from controls $(26 \pm 18 \mu \mathrm{M}, \mathrm{n}=14)$. After $7 \mathrm{~d}$ the sulfide level had increased to $424 \pm 122(\mathrm{n}=6)$, and reached $570 \pm 298 \mu \mathrm{M}(\mathrm{n}=18)$ at the end of the experiments. Thiosulfate concentration accumulated from $0.4 \pm 0.7 \mu \mathrm{M}(\mathrm{n}=13)$ in controls to a peak of 172 $\pm 49 \mu \mathrm{M}(\mathrm{n}=3)$ after $1 \mathrm{~d}$ of anoxic incubation and was $56 \pm 29 u \mathrm{M}$ after $10 \mathrm{~d}(\mathrm{n}=16)$.

Sulfite and cysteine were only present in traces and were not involved in sulfide detoxification (data not shown). GSH concentrations showed no variation. The level in hemolymph was $247 \pm 184 \mu \mathrm{M}(\mathrm{n}=11)$ in controls and $257 \pm 135 \mu \mathrm{M}(\mathrm{n}=18)$ after $10 \mathrm{~d}$ of anoxic incubation. In oxic sulfide experiments GSH concentrations were $232 \pm 74 \mu \mathrm{M}(\mathrm{n}=6)$ after $10 \mathrm{~d}$.

\section{Sulfide binding in the hemolymph}

Freshly sampled hemolymph of Halicryptus spinulosus was tested for the presence of a sulfide binding factor by means of equilibrium dialysis against ${ }^{35} \mathrm{~S}$ - radiolabelled sulfide. The hemolymph has a binding factor which concentrates sulfide nearly 2 -fold over the external sulfide concentration (Fig. 4). Hemolymph from specimens previously exposed to sulfide $(200 \mu \mathrm{M})$, and specimens kept in sulfide-free seawater prior to the experiment, bound radiolabelled sulfide, suggesting that some unlabelled sulfide in the hemolymph of exposed worms is exchanged for radiolabelled sulfide during dialysis.

The formation of a black fraction of the hemolymph during sulfide incubation occurs in the erythrocytes, since spinning of sulfide-incubated hemolymph resulted in a black pellet and clear supernatant. Spinning of either untreated hemolymph or lysed erythrocytes by ultrasonification with Centricon molecular weight cutoff membranes $(10 \mathrm{kDa})$ indicated that the black component was associated with the fraction above $10 \mathrm{kDa}$, since the black fraction did not pass the membrane.

\section{Succinate}

During oxic sulfide incubation $(200 \mu \mathrm{M})$ Halicryptus spinulosus accumulated only small amounts of succinate in the beginning of the experiments (Fig. 5). After $4 \mathrm{~d}$, levels of succinate increased significantly in hemolymph $\left(11.3 \pm 5.1 \mu \mathrm{mol} \mathrm{ml^{-1 }}\right)$ and body wall $(2.3$ $\pm 0.9 \mu \mathrm{mol} \mathrm{g}^{-1}$ fresh mass) with a trend of further accumulation after $10 \mathrm{~d}$ of incubation. This indicated that the worms could not maintain aerobic metabolism during long-term oxic sulfide exposure. Controls kept aerated before and during the experiments had succinate levels in the same range (Fig. 5). 

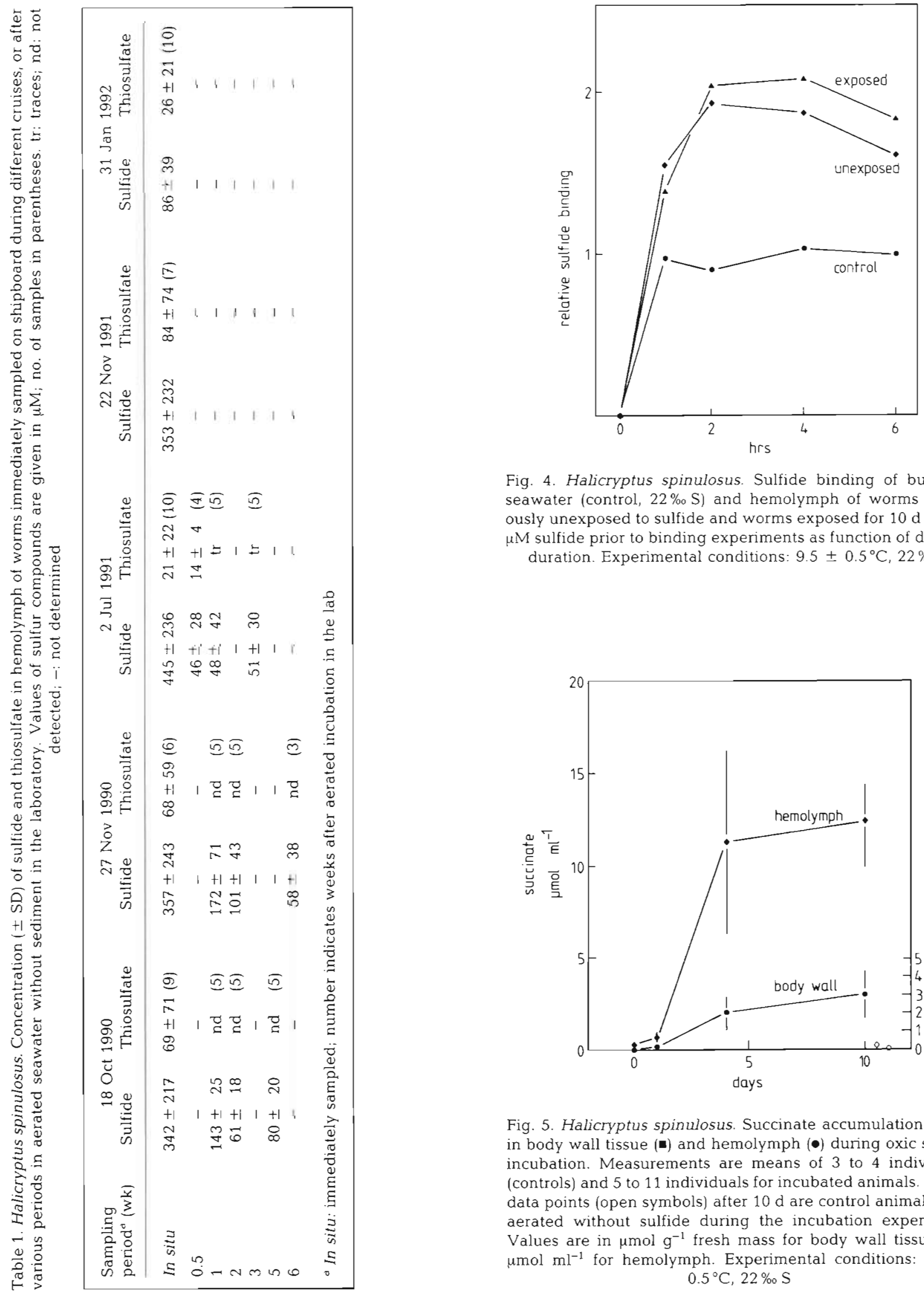

Fig. 4. Halicryptus spinulosus. Sulfide binding of buffered seawater (control, $22 \% \mathrm{~S}$ ) and henolymph of worms previously unexposed to sulfide and worms exposed for $10 \mathrm{~d}$ at 200 $\mu \mathrm{M}$ sulfide prior to binding experiments as function of dialysis duration. Experimental conditions: $9.5 \pm 0.5^{\circ} \mathrm{C}, 22 \% \mathrm{~S}$

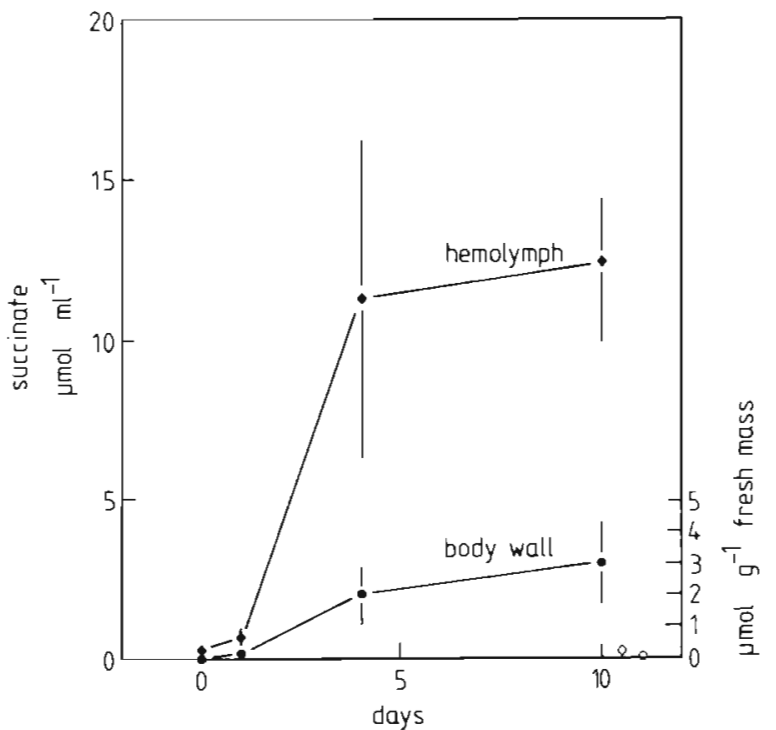

Fig. 5. Halicryptus spinulosus. Succinate accumulation $\pm S D$ in body wall tissue ( $\bullet$ ) and hemolymph ( $\bullet$ during oxic sulfide incubation. Measurements are means of 3 to 4 individuals (controls) and 5 to 11 individuals for incubated animals. Single data points (open symbols) after $10 \mathrm{~d}$ are control animals kept aerated without sulfide during the incubation experiment. Values are in $\mu \mathrm{mol} \mathrm{g}^{-1}$ fresh mass for body wall tissue and umol $\mathrm{ml}^{-1}$ for hemolymph. Experimental conditions: $9.5 \pm$ $0.5^{\circ} \mathrm{C}, 22 \% \mathrm{~S}$ 
Activity of cytochrome c oxidase and catalase

Activity of cytochrome c oxidase was low in the hemolymph. In vitro inhibition of cytochrome c oxidase by sulfide from body wall tissue $\left(K_{\mathrm{i}}\right)$ was $1.05 \pm 0.22$ $\mu \mathrm{M}$ sulfide, while in vivo activity in body wall tissue of individuals exposed to $200 \mu \mathrm{M}$ sulfide was ca $50 \%$ of that of unexposed controls (Table 2).

In vitro inhibitory constants of catalase for sulfide $\left(K_{\mathrm{i}}\right)$ were in the same range for hemolymph $198 \pm 25$ $\mu \mathrm{M})$ and body wall tissue $(201 \pm 32 \mu \mathrm{M})$. Activity of catalase in body wall tissue was not altered in vivo during $10 \mathrm{~d}$ of sulfide incubations $(200 \mu \mathrm{M})$ (Table 2 ). Catalase activity in body wall tissue previously sonicated to strip off the mucus covering the worms showed no significant difference to that of untreated worms. Sodium azide, a specific catalase inhibitor, reduced the activity of the enzyme nearly completely. A concentration of $250 \mu \mathrm{M}$ azide inhibited catalase activity in hemolymph by $86.4 \pm 2.8 \%(\mathrm{n}=5)$, and a concentration of $1 \mathrm{mM}$ inhibited the enzyme $94.4 \pm$ $2.4 \%(n=3)$. The activity of the enzyme from body wall tissue was almost entirely inhibited at $250 \mu \mathrm{M}$ azide $(97.8 \pm 3.8 \%, \mathrm{n}=3)$

\section{Mitochondria}

Different isolation procedures were tested. An isolation medium consisting of glycine and sucrose yielded maximal respiratory control rates (RCR). 2-oxoglutarate in the respiratory buffer was a prerequisite to measure respiration rates of Halicryptus spinulosus mitochondria. RCRs with succinate $(5 \mathrm{mM})$ as substrate were $1.72 \pm 0.12(n=11)$ with a maximum of 1.9. Mitochondrial preparations were cyanide-sensitive. Sulfide oxidation of the mitochondrial isolation was fast in the lower sulfide range: up to $11.3 \mathrm{nmol}$ sulfide $\mathrm{mg}^{-1}$ protein $\mathrm{min}^{-1}$ at $5 \mu \mathrm{M}$ (i.e. $6.5 \mathrm{nmol}$ sulfide in the assay) and up to $7.06 \mathrm{nmol}$ sulfide $\mathrm{mg}^{-1}$ protein min $^{-1}$ at $10 \mu \mathrm{M}$ (i.e. $13.0 \mathrm{nmol}$ sulfide in the assay). This rate might contain a certain fraction of an unspecific oxidation due to factors other than mitochondria. Sulfide inhibitory levels were $50 \mu \mathrm{M}$. More detailed mitochondrial sulfide oxidation characteristics need to be clarified in a further study.

\section{DISCUSSION}

When marine animals are confronted with environmental sulfide (its toxicity is attributed to the blocking of cytochrome c oxidase; National Research Council 1979), only limited defence responses are possible. Mobile fauna will be able to escape, unless the affected areas do not exceed small-scale ranges. Adult benthic macrofauna from soft sediments will be unlikely to escape into the water column, since these organisms generally have only very limited swimming capabilities. To live successfully in environments with the risk of frequent or regular exposure to sulfide, benthic macrofauna have to develop sulfide resistance as well as detoxification.

Adaptation to hydrogen sulfide can potentially take many forms in benthic infauna. Some mechanisms have been described but others doubtlessly remain to be elucidated. Mechanisms of sulfide resistance range from simple passive exclusion due to shell closure in bivalves to elaborate mitochondrial detoxification processes that produce ATP from sulfide oxidation (Powell \& Somero 1985, O'Brien \& Vetter 1990). Halicryptus spinulosus possesses some mechanisms known from other invertebrates as well as some new processes.

Aerobic respiration in Halicryptus spinulosus does

Table 2. Halicryptus spinulosus. Activity of cytochrome c oxidase and catalase in control (no sulfide) and anoxic sulfide exposed $(200 \mu \mathrm{M})$ worms. Values are means $\pm \mathrm{SD}$ in $\mathrm{U} \mathrm{ml}^{-1}$ for hemolymph or $\mathrm{U} \mathrm{g}^{-1}$ fresh mass for body wall tissue. Unit definitions: 1 unit of cytochrome c oxidase converts $1 \mu \mathrm{mol}$ of reduced cytochrome $\mathrm{min}^{-1} \mathrm{ml}^{-1}$ hemolymph or $\mathrm{g}^{-1}$ fresh mass of body wall tissue; 1 unit of catalase decomposes $1 \mu \mathrm{mol}$ of $\mathrm{H}_{2} \mathrm{O}_{2} \mathrm{~min}^{-1} \mathrm{ml}^{-1}$ hemolymph or $\mathrm{g}^{-1}$ fresh mass of body wall tissue. $50 \%$ inhibitory constants $\left(K_{\mathrm{i}}\right)$ are given in $\mu \mathrm{M} \pm \mathrm{SD}$ for sulfide. No. of samples are in parentheses. -: not determined

\begin{tabular}{|c|c|c|c|c|}
\hline & \multicolumn{2}{|c|}{ Cytochrome c oxidase } & \multicolumn{2}{|c|}{ Catalase } \\
\hline & $\begin{array}{l}\text { Hemolymph } \\
\left(\mathrm{U} \mathrm{ml}^{-1}\right)\end{array}$ & $\begin{array}{c}\text { Body wall } \\
\left(\mathrm{U} \mathrm{g}^{-1} \text { fresh mass }\right)\end{array}$ & $\begin{array}{l}\text { Hemolymph } \\
\left(\mathrm{U} \mathrm{ml}^{-1}\right)\end{array}$ & $\begin{array}{c}\text { Body wall } \\
\left(\mathrm{U} \mathrm{g}^{-1} \text { fresh mass) }\right.\end{array}$ \\
\hline Unexposed controls & $0.05 \pm 0.02(5)$ & $0.64 \pm 0.2(10)$ & $102.6 \pm 69.1(5)$ & $454.7 \pm 127.5(14)$ \\
\hline \multicolumn{5}{|c|}{$\begin{array}{l}\text { Sulfide exposed worms } \\
(200 \mu \mathrm{M}) \text { after: }\end{array}$} \\
\hline $1 \mathrm{~d}$ & - & - & - & $462.1 \pm 274.9(6)$ \\
\hline $8 \mathrm{~d}$ & $0.03 \pm 0.01(5)$ & $0.37 \pm 0.15(5)$ & - & - \\
\hline $10 \mathrm{~d}$ & - & - & - & $343.2 \pm 136.7(12)$ \\
\hline$K_{1}$ for sulfide $(\mu \mathrm{M})$ & - & $1.05 \pm 0.22(5)$ & $198 \pm 25$ & $201 \pm 32$ \\
\hline
\end{tabular}


not appear to be resistant to the effects of sulfide. Both intact mitochondria and specific enzymes show sulfide sensitivity at levels comparable to other organisms (Powell \& Somero 1986, Bagarinao \& Vetter 1990). H. spinulosus mitochondria are involved in sulfide oxidation. As in other marine organisms (Powell \& Somero 1986, Bagarinao \& Vetter 1990, O'Brien \& Vetter 1990) mitochondrial oxidation only works when sulfide concentration does not exceed a critical limit. When oxygen is available (as in the respiration chamber), mitochondria will oxidise sulfide. This process is cyanide sensitive. Preliminary studies on $H$. spinulosus mitochondria show that maximal oxidation rates are in the range of 5 to $10 \mu \mathrm{M}$ sulfide, while inhibitory levels are in the range of $50 \mu \mathrm{M}$ which is in agreement with other organisms tested so far (compilation in Bagarinao $\&$ Vetter 1990). ATP production in marine organisms using the proton potential generated by sulfide oxidation is generally low (Bagarinao \& Vetter 1990, O'Brien $\&$ Vetter 1990). In the case of $H$. spinulosus the oxidation of sulfide primarily seems to be used as a detoxification process.

In this context it is tempting to speculate about an analogous mechanism known from brown adipose tissue in hibernating mammals and heater cells involved in keeping endothermy in Scombroideid fish. Mitochondria of these tissues are uncoupled from ATP production to solely generate heat (as quoted in Hochachka \& Somero 1984, Block 1991). A similar ATP-independent mitochondrial sulfide oxidation clearly would facilitate sulfide detoxification. The involvement of mitochondria in sulfide detoxification in Halicryptus spinulosus is also proved by ultrastructural studies: mitochondria of epidermis and body wall tissue show altered electron densities caused by sulfide (Janssen \& Oeschger 1992). Moreover there were electron dense inclusions in epidermal mitochondria after sulfide incubation suggesting the deposition of substances resulting from sulfide detoxification.

Halicryptus spinulosus has an in vitro sulfide inhibition constant $\left(K_{1}\right)$ of cytochrome c oxidase of ca $1 \mu \mathrm{M}$. According to Bagarinao \& Vetter (1990) this is in the upper range known for marine organisms. Catalase, another sulfide-sensitive enzyme with a metal-containing catalytic centre (National Research Council 1979), has a much higher in vitro inhibition constant, about $200 \mu \mathrm{M}$ in body wall tissue and the hemolymph. In vivo activity of cytochrome c oxidase after $8 \mathrm{~d}$ of sulfide incubation $(200 \mu \mathrm{M})$ is about $50 \%$ of oxic control worms, while catalase is not affected (Table 2). Striking differences for cytochrome c oxidase inhibition in vitro and in vivo are due to different $\mathrm{pH}$ conditions in the cuvette (assay carried out at $\mathrm{pH}$ 6.0) and during whole worm incubation ( $\mathrm{pH}$ of ca 8.0 in the seawater). In vitro inhibition was tested by adding sulfide directly to the assayed tissue homogenate of unexposed control worms, while in vivo inhibition was determined by measuring actual remaining activity in tissue homogenates after incubation (for a more detailed discussion see Bagarinao \& Vetter 1990).

There is some evidence that both enzymes, cytochrome c oxidase and catalase, are mutually connected in their functioning. Morill et al. (1988) report catalase in thiobiotic meiofauna to be sulfide-insensitive like a bacterial pseudocatalase. In Halicryptus spinulosus a pseudocatalase is not found, since the enzyme is inhibited by azide, a specific catalase inhibitor. Nevertheless, a high sulfide concentration is needed to inhibit the enzyme in vitro, while no inhibition is detected in the range of realistic in vivo levels of sulfide $(200 \mu \mathrm{M})$. Undiminished catalase activity in $H$. spinulosus is against the general acceptance that catalase is important especially in habitats where oxygen and its radicals can reach toxic levels. Catalase might be needed to protect $H$. spinulosus in the presence of sulfide, since inorganic reactions of sulfide can produce oxygen radicals and $\mathrm{H}_{2} \mathrm{O}_{2}$ (Millero 1986). Inhibition of cytochrome $\mathrm{c}$ oxidase by sulfide results in elevated levels of superoxide radicals and $\mathrm{H}_{2} \mathrm{O}_{2}$ due to increased amounts of reduced forms of respiratory chain components and tissue hypoxia may even aggravate this situation (Khan et al. 1990). In vertebrates hypoxia can activate xanthine oxidase which in the presence of sulfide stimulates the production of $\mathrm{O}_{2}^{--}$(cf. Khan et al. 1990). Should sulfide thus produce increased amounts of toxic oxygen compounds, a maintained activity of catalase in the presence of sulfide clearly would be advantageous.

No marine animal is now able to exclude external sulfide from entering into the body (e.g. meiofauna: Powell et al. 1979; Crustacea: Vetter et al. 1987, Vismann 1991b; fish: Bagarinao \& Vetter 1989). Under aerobic conditions Halicryptus spinulosus is able to keep sulfide concentrations in the body low for a certain time, even at high external sulfide concentrations $(200 \mu \mathrm{M})$. Under this condition sulfide in body wall tissue increases slightly after $4 \mathrm{~d}$ probably due to a decreasing sulfide oxidation capacity. Hemolymphic sulfide concentration only increases somewhat after $10 \mathrm{~d}$. High levels of thiosulfate, a non-toxic detoxification product of sulfide, are found in body wall tissue and hemolymph.

Halicryptus spinulosus is able to keep an internal aerobic sulfide oxidation for ca $4 \mathrm{~d}$. The onset of anaerobic pathways, i.e. sulfide-induced anaerobiosis, is indicated after $1 \mathrm{~d}$ due to a slight succinate accumulation, a typical anaerobic metabolite. In the subsequent days the worms accumulate considerable amounts of succinate, indicating an elevated fraction of anaerobiosis. The recourse to anaerobic pathways goes 
against the classical definition of anaerobiosis as being triggered by the absence of oxygen. Sulfide as a trigger of anaerobiosis in the presence of oxygen has been reported so far in the case of Solemya reidi (Anderson et al. 1990) and most recently in Sipunculus nudus and Arenicola marina (Völkel \& Grieshaber 1992)

When the environment becomes anoxic and sulfidic Halicryptus spinulosus appears to use a short-term defence to control influx of external sulfide. $H$. spinulosus differs from all previously studied organisms

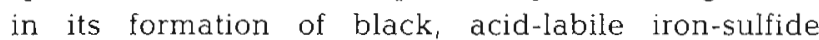
interactions, which may produce Mackinawite-like (FeS) or Greigite-like $\left(\mathrm{Fe}_{3} \mathrm{~S}_{4}\right)$ compounds, and the ease in which it can apparently reverse this process. The conspicuous blackening of the worms is attributed to sulfide reacting with iron (mostly $\mathrm{Fe}^{2+}$ ) which is present in large amounts on the cuticle. Thus a first protection against sulfide is achieved (Oeschger \& Janssen 1991). The effect of this mechanism is confirmed by ultrasonification. When the outer, iron-sulfide containing mucus is removed, body wall tissue contains less sulfide. A similar mechanism is discussed for internal iron deposits supposed to participate in sulfide detoxification in the gut of echinoderms (Buchanan et al. 1980, de Ridder et al. 1985) and in the mid-gut gland of an isopod (Vismann 1991b). An outer shield in $H$. spinulosus seems advantageous when the worms burrow in deeper sediment layers where they may encounter varying concentrations of sulfide (Fig. 1). A certain degree of blackening of the cuticle also occurs during oxic sulfide incubation. About $50 \%$ of the incubated worms became black after $3 \mathrm{~d}$. This outer shield is rechargeable as previously reported. Oxygen reverses the colour change (Oeschger \& Janssen 1991). The black colour also disappears when treated with acidic solutions

Such a striking colour change in a marine invertebrate related to sulfide exposure and its involvement in sulfide detoxification has not yet been reported. $\mathrm{O}_{2}$ independent oxidation of sulfide mediated by iron ions is also reported for anoxic seawater (Millero 1991a, b). At the present we can only speculate about similarities of these mechanisms.

Sulfide oxidation to thiosulfate under anoxia is only of minor importance. At the beginning of the experiments a small increase of thiosulfate in body wall tissue and hemolymph was detected. We attribute this to an oxygen supply limited by the storage capacity of hemerythrin, the respiratory pigment of priapulids. Thus, other mechanisms must be effective. Halicryptus spinulosus binds some sulfide to a yet unknown hemolymphic-borne binding factor. Buffering of sulfide by binding should be another short-term defence, although a 2 -fold sulfide-concentration capacity in $H$. spinulosus is moderate compared to a 6 -fold one in
Escarpia laminata, a vestimentiferian worm (Cary et al. 1989a). Sulfide binding proteins have so far only been found in marine animals with endosymbionts (Arp et al. 1984, 1987, Cary et al. 1989a) and might also be present as an iron-protein complex in the mid-gut gland of Saduria entomon (Vismann 1991b). The hemolymphic binding factor of $H$. spinulosus explains a 2- to 3 -fold accumulation of sulfide over external levels, which would be impossible according to the laws of diffusion. High hemolymphic sulfide levels (up to $80 \mu \mathrm{M}$ ) after 5 to 6 wk of aerated incubation (Table 1) or in controls (Fig. 3a) indicate that the binding factor releases sulfide very slowly. This is supported by the absence of thiosulfate after prolonged incubation (Table 1). Sulfide binding in $H$. spinulosus may result in a certain fraction of acid-volatile sulfide as reported for Saduria entomon (Vismann 1991b). This still has to be elucidated for the priapulid worm. In such a case elevated sulfide levels are attributed to a bound acid-labile fraction which does not harm the animals.

A distinct colour change of the hemolymph of Halicryptus spinulosus after ca $3 \mathrm{~d}$ of anoxic sulfide incubation indicates that the hemerythrin reacts with sulfide. Hemerythrin is known to contain a substantial amount of iron (Klotz et al. 1957), so that an iron-sulfide interaction seems likely. In contrast to hemoglobin, hemerythrin binds oxygen by changing its valence from $\mathrm{Fe}^{2+}$ to $\mathrm{Fe}^{3+}$ (Klotz et al. 1957, Klippenstein 1980). Our preliminary studies on the coelomic fluid show that the black component is associated in the erythrocytes and has a molecular weight $>10 \mathrm{kDa}$, when we used a centrifugation procedure that excludes molecules of this size. Thus we can rule out formation of a free ironsulfide complex, which would have passed the membrane due to its molecular size. At this time we can only speculate on a binding to the hemerythrin since hemolymph regains its usual pinkish colour when oxygen is present. Our findings are in accordance with Schreiber et al. (1990), who reported a major hemolymph iron-containing constituent of ca $12 \mathrm{kDa}$ with tightly bound iron. This binding is not disturbed by treatments of strong detergents, reducing agents or heat denaturation, and represents the respiratory pigment, i.e. hemerythrin, of the animals. Sulfide binding implies a release at a later time. Presently we do not know if the sulfide will be released when the pigment is reoxidised or if it is released as an oxidised form of sulfide. Presumably the oxygen-binding capacity will be destroyed by sulfide binding. It has yet to be elucidated if the sulfide binding means a beneficial adaptation or if it is a mere chemical interaction between sulfide and respiratory pigment.

Binding of sulfide may at least temporarily prevent mitochondria in Halicryptus spinulosus from being poisoned since these organells are obviously important 
in sulfide detoxification. But this may only work as a short-term protection depending on the oxygen storage capacity of the hemerythrin. A putative enzymatic sulfide oxidase activity separate from mitochondria has previously been reported (Powell \& Somero 1985). Due to non-physiological assay conditions the method used to demonstrate such a specific enzymatic activity has been doubted (Bagarinao \& Vetter 1990). So far there is no evidence for a specific enzyme and its physiological relevance. Spontaneous sulfide oxidation catalysed by metal ions (Chen \& Morris 1972) may be a large portion of the 'sulfide oxidase' activities. Thus mitochondrial sulfide oxidation confirmed for the bivalve Solemya reidi (Powell \& Somero 1986) and marine fish (Bagarinao \& Vetter 1990) might be the only welldocumented sulfide oxidation system at physiologically realistic conditions.

This study also suggests that anaerobiosis is involved in sulfide resistance. Halicryptus spinulosus has a remarkable anaerobic capacity (Oeschger 1990). Succinate accumulation during oxic sulfide incubation shows that the worms rely to an increasing degree on anaerobic metabolism. Obviously $H$. spinulosus has to switch to anaerobiosis when sulfide influx becomes too high for detoxification to keep up. Worms will be forced to passively survive this adverse environmental condition by becoming metabolically quiescent. Calorimetric studies prove an enormous metabolic reduction (Oeschger et al. 1992). Such a reduction will also be an advantage during elevated sulfide exposure. In $H$. spinulosus anaerobic glycolysis is not affected by the presence of sulfide over $10 \mathrm{~d}$ (Oeschger \& Storey 1990). On the other hand one has to take into consideration that accumulating acidic anaerobic metabolites will cause a substantial drop in internal $\mathrm{pH}$. Such a decrease intensifies sulfide toxicity. Thus the accumulation of acidic end-products might be an essential factor affecting long-term survival. At a physiological $\mathrm{pH}$ of ca 7.6 to 8.0 the toxic form of sulfide, the uncharged molecule $\mathrm{H}_{2} \mathrm{~S}$, is present at 10 to $20 \%$ (A.PHA 1985). When pH drops, e.g. to 7.0, ca $50 \%$ of sulfide will be present in the uncharged form $\left(\mathrm{H}_{2} \mathrm{~S}\right)$ which will readily penetrate membranes. Even though glycolysis is not affected in $H$. spinulosus, an aggravation due to elevated sulfide influx with concomitant increase of undissociated toxic $\mathrm{H}_{2} \mathrm{~S}$ as a result of a decreasing internal $\mathrm{pH}$ seems to be unavoidable. During long-term sulfide exposure this may lead to fatal interferences with metabolic processes.

\section{Whole animal model of sulfide control}

The presented data allow an overall model of sulfide detoxification and resistance to be made in a marine invertebrate from soft sediment. External sulfide is partly immobilised on the outer mucus barrier by precipitating iron-sulfides, made visible by blackening of Halicryptus spinulosus. When sulfide exposure prevails above the precipitation capacity, toxic sulfide entering the worm is oxidised to thiosulfate, the major detoxification product. Thiosulfate production depends on oxygen availability. When sulfide concentration exceeds a specific threshold, aerobic pathways are supplemented by an increasing fraction of fermentative ATP production.

Simultaneously or upon exhaustion of oxygen or detoxification capacity in mitochondria, a hemolymphic binding factor, which seems identical with hemerythrin, also limits free sulfide concentration. This process may help to keep mitochondria from being poisoned to a certain degree. Later the hemerythrin also blackens when obviously being involved in sulfide binding. When these mechanisms of sulfide control are overwhelmed by further sulfide influx, Halicryptus spinulosus switches entirely to anaerobic energy metabolism. This is to passively outlast sulfide. On return to oxic non-sulfidic conditions, worms regain their pale colour by reversible iron-sulfide splitting. $H$. spinulosus can reverse inorganic iron-sulfide formation and restore hemerythrin function. Further research should be directed to elucidating the nature of these protein-bound, iron-sulfur compounds and the biochemical mechanism of their reversal.

Acknowledgements. R.O. thanks Prof. Dr H. Theede for generous support during this study. The authors are indebted to D. Wilmot, La Jolla, USA, for carrying out the sulfide binding experiments and to Petra Wencke for excellent and skillful technical assistance. Thanks are further due to U. Fiedler, Kiel, Germany, for help with collecting the animals and to the Institut für Meereskunde, Kiel, for providing ship time. Anonymous referees provided helpful comments on the manuscript. This research was supported by a travel grant and a grant-in-aid by the Deutsche Forschungsgemeinschaft to R.O. (Oe 124/2-1) and the Bundesminister für Forschung und Technologie (03 F0045A).

\section{LITERATURE CITED}

Aebi, H. E. (1985). Catalase. In: Bergmeyer, H. U. (ed.) Methods of enzymatic analysis, Vol. III. Verlag Chemie, Weinheim, p. 273-286

Anderson, A. E., Felbeck, H., Childress, J. J. (1990). Aerobic metabolism is maintained in animal tissue during rapid sulfide oxidation in the symbiont-containing clam Solemya reidi. J. exp. Zool. 256: 130-134

APHA (American Public Health Association), American Water Works Association, and Water Pollution Control Federation (1985). Standard methods for the examination of water and wastewater, 16th edn. American Public Health Association, Washington, D.C.

Arp, A. J., Childress, J. J., Fisher C. R., Jr (1984). Metabolic and blood gas transport characteristics of the hydrothermal 
vent bivalve Calyptogena Magnifica. Physiol. Zool. 57 : 648-662

Arp, A. J., Childress, J. J., Vetter, R. D. (1987). The sulphidebinding protein in the blood of the vestimentiferan tubeworm, Riftia pachyptila, is the extracellular haemoglobin. J. exp. Biol. 128: 139-158

Bagarinao, T., Vetter, R. D. (1989). Sulfide tolerance and detoxification in shallow-water marine fishes. Mar. Biol. 103: 291-302

Bagarinao, T., Vetter, R. D. (1990). Oxidative detoxification of sulfide by mitochondria of the California killifish Fundulus parvipinnis and the speckled sanddab Citharichthys stigmaeus. J. comp. Physiol. (Sect. B) 160: 519-527

Beutler, H. O. (1985). Succinate. In: Bergmeyer, H. U. (ed.) Methods of enzymatic analysis, Vol. VII. Verlag Chemie, Weinheim, p. 25-33

Block, B. A. (1991). Evolutionary novelities: how fish have built a heater out of muscle. Am. Zool. 31: 726-742

Buchanan, J. B., Brown, B. E., Coombs, T. L., Pirie, B. J. S., Allan, J. A. (1980). The accumulation of ferric iron in the guts of some spatangoid echinoderms. J. mar. biol. Ass. U.K. 60: 631-640

Cary C., Fry, B., Felbeck, H., Vetter, R. D. (1989a). Multiple trophic resources for a chemoautotrophic community at a cold water brine seep at the base of the Florida Escarpment. Mar Biol. 100: 411-418

Cary, C., Vetter, R. D., Felbeck, H. (1989b). Habitat characterization and nutritional strategies of the endosymbiontbearing bivalve Lucinoma aequizonata. Mar. Ecol. Prog. Ser. 55: 31-45

Cavanaugh, C. M., Gardiner, S. L., Jones, M. L., Jannasch, H. W., Waterbury, J. B. (1981). Procaryotic cells in the hydrothermal vent tube worm Riftia pachyptilla Jones: possible chemoautotrophic symbionts. Science 213: 340-342

Chen, K. Y., Morris, J. C. (1972). Oxidation of sulfide by $\mathrm{O}_{2}$ catalysis and inhibition. J. sanit. Engng Div. Am. Soc. civ Engrs SA 1. 215-227

Cline, J. D. (1969). Spectrophotometric determination of hydrogen sulfide in natural waters. Limnol. Oceanogr. 14: $454-458$

de Ridder, C., Jangoux, M., de Vos, L. (1985). Description and significance of a peculiar intradigestive symbiosis between bacteria and a deposit-feeding echinoid. J. exp. mar. Biol. Ecol. 9: $65-76$

Estabrook, R. W. (1967). Mitochondrial respiratory control and the polarographic measurement of ADP:O ratios. Methods Enzymol. 10: 41-47

Fahey, R. C., Newton, G. L. (1987). Determination of lowmolecular-weight thiols using momobromobimane fluorescent labeling and high-performance liquid chromatography. Methods Enzymol. 143: 85-97

Fisher, C. R. (1990). Chemoautotrophic and methanotrophic symbioses in marine invertebrates. CRC Rev. aquat. Sci. 2: $399-436$

Hand, S. C., Somero, G. N. (1983). Energy metabolism pathways of hydrothermal vent animals: adaptations to a foodrich and sulfide-rich deep-sea environment. Biol. Bull. 165: $167-181$

Hochachka, P. W., Somero, G. N. (1984). Biochemical adaptation. Princeton University Press, Princeton

Ingrorsen, K., Jörgensen, B. B. (1979). Combined measurement of oxygen and sulfide in water samples. Limnol. Oceanogr. 24: 390-393

Janssen, H. H., Oeschger, R. (1992). The body wall of Halicryptus spinulosus (Priapulida) - ultrastructure and changes induced by hydrogen sulfide. Hydrobiologia 230 $219-230$
Jones, M. L. (1985). The hydrothermal vents of the Eastern Pacific: an overview. Bull. Biol. Soc. Wash. 6: 1-5

Khan, A. A., Schuler, M. M., Prior, M. G., Yong, S., Coppock, R. W., Florence, L. Z., Lillie, L. E. (1990). Effects of hydrogen sulfide exposure on lung mitochondrial respiratory chain enzymes in rats. Toxic. appl. Pharmac. 103: 482-490

Klippenstein, G. L. (1980). Structural aspects of hemerythrin and myohemerythrin. Am. Zool. 20: 39-51

Klotz, I. M., Klotz, T. A., Fiess, H. A. (1957). The nature of the active site of hemerythrin. Arch. Biochem. Biophys. 68: $284-299$

Llansó, R. J. (1991). Tolerance of low dissolved oxygen and hydrogen sulfide by the polychaete Streblospio benedicti (Webster). J. exp. mar. Biol. Ecol. 153: 165-178

Meischner, D., Rumohr, J. (1974). A light-weight, highmomentum gravity corer for subaqueous sediments. Senckenbergiana marit. 6: 105-117

Millero, F. J. (1986). The thermodynamics and kinetics of the hydrogen sulfide system in natural waters. Mar. Chem. 18: $121-147$

Millero, F. J. (1991a). The oxidation of $\mathrm{H}_{2} \mathrm{~S}$ in Black Sea waters. Deep Sea Res. 38, Suppl. 2: 1139-1150

Millero, F. J. (1991b). The oxidation of $\mathrm{H}_{2} \mathrm{~S}$ in the Chesapeake Bay. Estuar. coast. Shelf Sci. 33: 521-527

Morrill, A. C., Powell, E. N., Bidigare, R., Shick, J. M. (1988), Adaptations to life in the sulfide system: a comparison of oxygen detoxifying enzymes in thiobiotic and oxybiotic meiofauna (and freshwater planarians). J. comp. Physiol. (Sect. B) 158: 335-344

National Research Council, Division of Medical Science, Subcommittee on hydrogen sulfide (1979). Hydrogen sulfide. University Park Press, Baltimore

O'Brien, J., Vetter, R. D. (1990). Production of thiosulphate during sulphide oxidation by mitochondria of the symbiont-containing bivalve Solemya reidi. J. exp. Biol. 149 133-148

Oeschger, R. (1990). Long-term anaerobiosis in sublittoral marine invertebrates from the Western Baltic Sea: Halicryptus spinulosus (Priapulida), Astarte borealis and Arctica islandica (Bivalvia). Mar. Ecol. Prog. Ser. 59: 133-143

Oeschger, R., Janssen, H. H. (1991). Histological studies on Halicryptus spinulosus (Priapulida) with regard to environmental hydrogen sulfide resistance. Hydrobiologia 222: $1-12$

Oeschger, R., Peper, H., Graf, G., Theede, H. (1992). Metabolic responses of Halicryptus spinulosus (Priapulida) to reduced oxygen levels and anoxia. J. exp. mar. Biol. Ecol. in press

Oeschger, R., Storey, K. B. (1990). Regulation of glycolytic enzymes in the marine invertebrate Halicryptus spinulosus (Priapulida) during environmental anoxia and exposure to hydrogen sulfide. Mar. Biol. 106: 261-266

Ott, J. A., Novak, R., Schiemer, F., Hentschel, U., Nebelsick, M., Polz, M. (1991). Tackling the sulfide gradient: a novel strategy involving marine nematodes and chemoautotrophic ectosymbionts. P.S.Z.N.I. Mar. Ecol. 12: 261-279

Powell, E. C, Crenshaw, M. A., Rieger, R. M. (1979). Adaptations to sulfide in the meiofauna of the sulfide system. I. ${ }^{35} \mathrm{~S}$-sulfide accumulation and the presence of a sulfide detoxification system. J. exp mar Biol. Ecol. 37: 57-76

Powell, M. A., Somero, G. N. (1983). Blood components prevent sulfide poisoning of respiration of the hydrothermal vent tube worm Riftia pachyptila. Science 219: 297-299

Powell, M. A., Somero, G. N (1985). Sulfide oxidation occurs in the animal tissue of the gutless clam, Solemya reidi. Biol. Bull. 169: 164-181

Powell. M. A., Somero, G. N. (1986). Hydrogen sulfide oxida- 
tion is coupled to oxidative phosphorylation in mitochondria of Solemya reidi. Science 233: 563-566

Schiemer, F., Novack, R., Ott, J. (1990). Metabolic studies on thiobiotic free-living nematodes and their symbiotic microorganisms. Mar Biol. 106: 129-137

Schreiber, A., Storch, V., Powilleit, M., Higgins, R. P. (1990). The blood of Halicryptus spinulosus (Priapulida). Can. J. Zool. 69: 201-207

Somero, G. N., Childress, J. J., Anderson, A. E. (1989). Transport, metabolism, and detoxification of hydrogen sulfide in animals from sulfide-rich marine environments. CRC crit. Rev. aquat. Sci. 1: 591-614

Theede, H. (1984). Physiological approaches to environmental problems of the Baltic. Limnologica 15: 443-458

Theede, H., Ponat, A., Hiroki, K., Schlieper, C. (1969). Studies on the resistance of marine bottom invertebrates to oxygendeficiency and hydrogen sulphide. Mar. Biol. 2: 325-337

Vetter, R. D., Matrai, P. A., Javor, B., O'Brien, J. (1989). Reduced sulfur compounds in the marine environment. In:

This article was submitted to the editor
Saltzman, E. S. Cooper, W. J. (eds.) Biogenic sulfur in the environment. American Chemical Society Symposium Series No. 393, p. 243-261

Vetter, R. D., Wells, M. E., Kurtsman, A. L., Somero, G. N. (1987). Sulfide detoxification by the hydrothermal vent crab Bythograea thermydron and other decapod crustaceans. Physiol. Zool. 60: 121-137

Vismann, B. (1991a). Sulfide tolerance: physiological mechanisms and ecological implications. Ophelia 34:1-27

Vismann, B. (1991b). Physiology of sulfide detoxification in the isopod Saduria (Mesidotea) entomon. Mar Ecol. Prog. Ser. 76: 283-293

Völkel, S., Grieshaber, M. K. (1992). Mechanisms of sulphide tolerance in the peanut worm, Sipunculus nudus (Sipunculidae) and in the lugworm, Arenicola marina (Polychaeta). J. comp. Physiol. (Sect. B) 162: in press

Weigelt, M., Rumohr, H. (1986). Effects of wide range oxygen depletion on benthic fauna and demersal fish in Kiel Bay 1981-1983. Meeresforsch. 31: 124-136

Manuscript first received: May 5, 1992

Revised version accepted: July 16, 1992 